\title{
A Cross Cultural Analysis of Textual and Interpersonal Metadiscourse Markers: The Case of Economic Articles in English and Persian Newspapers
}

\author{
Abbas Mehrabi Boshrabadi (Corresponding author) \\ English Department, Islamic Azad University, Khorasgan (Isfahan) Branch, \\ PO box 81595-158, Isfahan, Iran \\ E-mail: abbas.mehrabi596@gmail.com \\ Reza Biria \\ English Department, Islamic Azad University, Khorasgan (Isfahan) Branch, \\ PO box 81595-158, Isfahan, Iran \\ E-mail: r_biria@yahoo.com \\ Zahra Zavari \\ Faculty of Humanities, Islamic Azad University, Najafabad Branch, \\ PO box 517, Najafabad, Iran \\ E-mail: zahrazavari@yahoo.com
}

Doi:10.7575/aiac.alls.v.5n.2p.59

URL: http://dx.doi.org/10.7575/aiac.alls.v.5n.2p.59
Received: 09/02/2014

Accepted: 28/03/2014

\begin{abstract}
This study was an attempt to investigate the functional role of textual and interpersonal metadiscourse markers in English and Persian Economic news reports. To this end, 10 news articles, 5 in each language, were randomly selected from the Economic sections of the leading newspapers published in 2013-2014 in Iran and the United States. Based on Kopple's (1985) taxonomy, the type and frequency of metadiscourse markers used in the texts were analyzed to find out their functions in the text. The findings revealed that the textual markers used by Persian authors were considerably more frequent than those employed by the American writers. Interestingly, unlike the Persian writers, the American authors enlisted a larger number of interpersonal markers, which made their angle of the subject treatment different. It is evident that the differential use of metadiscourse markers by nationally different authors could be attributed to culturespecific norms governing the development and organization of discourse.
\end{abstract}

Keywords: Metadiscourse markers, Economic news articles, Newspaper discourse, Interpersonal metadiscourse markers, Textual metadiscourse markers

\section{Introduction}

Metadiscourse, a relatively new concept in the area of discourse analysis, refers to the ways speakers and writers address and communicate with their audience. It embodies the idea that writers and speakers should go beyond the ideational dimension, or propositional content, of text and speech in order to communicate their message effectively. As such, metadiscourse is a term used by most practitioners of the field so as to refer to the textual resources beyond sentence or pragmatic levels. Rather than only representing their ideas and information through language, writers need to consider the expectations and requirements of their receivers so as to engage them in the reading process and affect their understanding of the discourse produced. This view, as Dafouze-Milne (2008) maintains, is based on the assumption that writing is a social and communicative process and, in this regard, metadiscourse is used to organize and create a given text by involving the reader and expressing the author's inputs and stances.

According to Halliday (1994), language can be functionally divided into three categories; namely, ideational, interpersonal, and textual. While ideational function refers to the information the writer or speaker communicates, interpersonal function is concerned with the way language establishes, maintains, and signals relations among people. Finally, textual function of language aims at creating coherent written and spoken texts related to its audience as well as its context. However, the focus of the present study is on the textual and interpersonal functions of the language known as metadiscourse.

The concept of metadiscourse has been defined differently by various researchers. Vande Kopple (1985), as an example, defines metadiscourse as "discourse that people [writers] utilize to expand referential material and help their readers connect, organize, interpret, evaluate, and develop attitudes towards that material" (P. 83). As Kopple puts it, writers work on two levels. On the primary level, the propositional content or the information about subject matter is satisfied; on the metadiscourse level, nothing is added to the content but the readers are engaged in finding out the message and the writer's views; in fact, writers focus on how they are communicating with the readers. Clearly, 
according to Vande Kopple, primary discourse is primarily concerned with the ideational function, whereas metadiscourse is related to the textual and interpersonal functions of language.

Focusing on the definition provided by Vande Kopple (1985), in 1998, Hyland organized metadiscourse markers into two main categories, viz, textual and interpersonal. As Hyland maintains, the textual metadiscourse elements can be, based on the functions they serve in the text, further divided into five subtypes; namely, Endophoric Markers, Frame Markers, Logical Connectives, Code Glosses, and Evidentials. The first category, endophoric markers, can be described as the linguistic elements referring to the earlier materials in the text so as to support the argument and help readers understand the text better (e.g., as noted above). Frame markers are words or phrases that sequence parts of a text (e.g., first, then, at the same time) or change the topic (e.g., lets return to, now) or label the text stages (e.g., finally, to summarize). Logical connectives, as the name suggests, semantically connect the main ideas that are internal to text. They are mostly conjunctives and adverbial phrases such as in addition, but, therefore, and likewise. Code glosses are the next category of metadiscourse markers. As Hyland (2005, P. 52) states, code glosses are "textual devices that supply additional information by rephrasing, explaining or elaborating what has been said, to ensure the reader recovers the writer's intended meaning" (e.g., namely, in other words, such as). And finally, evidentials refer to the sources of information from other texts. The utility of evidentials by authors or researchers is mostly to provide evidence for their work by citing the works or ideas of other authors (e.g., according to X, as X puts it, X states that).

The interpersonal metadiscourse markers, on the other hand, provide the writers with linguistic elements so as for them to express their attitudes and perspectives toward the propositional content of the text. These linguistic signals help writers to engage the readers in the text by addressing them directly. Along the same line with textual metadiscourse markers, Hyland (1998) also classified the interpersonal metadiscourse markers into five major categories: Emphatics, Hedges, Person Markers, Relational Markers, and Attitude Markers. Emphatics can be described as metadiscourse markers writers use in order to express their certainty concerning an idea, or to emphasize their claims in the text by such linguistic elements as certainly, definitely, and it is obvious. However, when writers are uncertain about the truth of their claims they employ linguistic entities like might, perhaps, it is possible, etc. These subtypes of metadiscourse markers are referred to as "hedges". There are also situations in which writers desire to convey their presence in the text. In such cases, they enlist linguistic items called "Person Markers"; examples of such markers include $I$, we, my, and mine. The other type of interpersonal metadiscourse markers is relational markers by which writers directly refer to or build relationship with the readers. Phrases like Dear reader, please consider, and note that, are but a few examples of relational markers. And the last category subsumed within the interpersonal metadiscourse markers classification includes "attitude markers". They are employed when writers are in need of communicating their perspectives and attitudes towards the propositional content of the text. For example, words or phrases such as surprisingly, I agree, and I hope, fall into such category.

Accordingly, metadiscourse markers, as Hyland (2005) believes, are linguistic elements writers (or speakers) utilize to not only exchange the information, but also express their attitudes, personalities, and assumptions by addressing and interacting with the receivers of the message. Hyland further argue that in this way, "the writer is not simply presenting information about the suggested route by just listing changes of direction, but taking the trouble to see the walk from the reader's perspective" (P. 3). Using metadiscourse markers in the text, writers would be able to instantiate the intended propositional content and their ideas both coherently and intelligibly for revealing the maze of their units of thoughts to the readers. Furthermore, metadiscourse markers would build an interaction between the reader and writer and account for the atmosphere and reader-friendliness of the text (Hyland \& Tse, 2004). For instance, writers intelligibly communicate their own ideas when they employ illocution markers such as I recommend that, or I believe that; or they inform readers about the degree of their certainty in making a proposition with regard to a given idea by applying hedges like perhaps, might, and apparently as well as emphatics such as clearly, undoubtedly, and surely.

\section{Review of Relevant Literature}

Indubitably, metadiscourse is claimed to be an important area in discourse analysis in that it helps writers to convey their intended message effectively by creating a social and communicative interaction with the reader. Through using metadiscourse markers, writers would be capable of creating a coherent text and thus increasing the efficiency of the text. As a result of these and other merits of the utility of metadiscourse markers in the text, metadiscourse analysis has recently captured the attention of many practitioners of the field and a wide range of empirical studies have been conducted in various genres and contexts including, but not limited to, academic writing (Hyland \& Tse, 2004; Simin \& Tavangar, 2009; VahidDastjerdi \& Shirzad, 2010), research articles (Abdi, 2002; Zarei \& Mansouri, 2011), and newspaper discourse (Abdollahzadeh, 2007; Hashemi \& Golparvar, 2012).

The first, and most important, area of investigation regarding the role of metadiscourse markers in the text has focused on the persuasive function of these linguistic elements. Metadiscourse markers play an important role in persuasive writing and act as persuasive tools which writers utilize in their texts to influence the readers. Hyland (2005) addresses this issue stating that metadiscourse markers, if used properly, might contribute to the art of persuasion by virtue of the fact that they foster logical appeal once they directly associate ideas with arguments, and indicate approval if they are in line with the reader's way of thinking. In this regard, Dafouz-Milne (2003) examined the use of interpersonal and textual metadiscourse markers in the opinion columns of two elite newspapers: the Spanish El Pais and the British The Times. Using 40 opinion articles, 20 in each newspaper, as her corpus materials, Dafouz concluded that the frequency of textual metadiscourse markers (e.g., logical connectives, code glosses) used by Spanish writers was more than that of English reporters, whereas the British writers used more instances of interpersonal markers (e.g., hedges, attitude markers) compared with the Spanish news reporters. 
Abdollahzadeh (2007) also tried to investigate the ways writers with different cultures organize their written texts by using metadiscourse markers. To this end, he analyzed 53 Persian and English (British and U.S) newspaper editorials. The results indicated no significant difference between Persian and English editorials for the metadiscourse subtypes of text connectives, attitude markers, and person markers. Concerning the interpersonal metadiscourse markers, however, it was found that English editorials used more hedges while Persian editorials used more emphatics. The researcher concluded that the frequent use of emphatics by the Persian editorial writers was most likely due to an Iranian tradition of valuing and abiding by the rules of those in power without questioning them or without expressing uncertainty about social and, especially, religious issues. On the other hand, the heavy use of hedges by the English editorial writers was related to their being more considerate and polite to their readers.

Along the same line, Noorian and Biria (2010) investigated the frequency and degree of the use of interpersonal metadiscourse markers in persuasive discourse. In this study, the metadiscourse markers used in English opinion articles written by American and Iranian columnists were compared. The results revealed that interpersonal metadiscourse markers were present in both sets of corpora, but there were significant differences between the two groups regarding the occurrences of interpersonal markers, especially in the case of Commentaries. The findings also suggested that different factors such as culture-driven preferences, genre-driven conventions, and Iranian EFL writers' extent of foreign language experience interacted in choosing the interpersonal metadiscourse markers by the columnists.

Regarding the frequency of the use of different metadiscourse markers in newspapers discourse, in 2012, Hashemi and Golparvar investigated the textual and interpersonal metadiscourse markers used in Persian news reports. The results indicated that metadiscourse markers were frequently utilized in Persian news reports and also the number of textual metadiscourse markers was much higher compared with interpersonal metadiscourse markers. Along the same line, Yazdani, Sharifi, and Elyassi (2014) tried to examine the role interpersonal metadiscourse markers play in Political English and Persian news articles. Choosing 30 news articles extracted from both languages and using Hyland's (2005) classification of interpersonal metadiscourse markers, they tried to discover the existing differences between the two languages. The results indicated that there was a statistically significant difference between two sets of data in terms of the frequency of interpersonal markers. The findings reflected that American journalists tended to use these linguistic items more frequently in their news articles. Moreover, it was concluded that Iranian writers, in formal contexts, did not show a tendency towards using personal markers such as $I$, we, and our, in writing news articles; instead, they preferred to apply third person pronouns and passive structures to address the reader about their ideas.

Obviously, metadiscourse analysis has been dealt with in a number of empirical studies focusing on different genres and contexts, as was mentioned above. However, few studies, if any, have considered the role of metadiscursive elements in Economic newspaper reports. As Crismore and Abdollahzadeh (2010) claim, little attention has been paid to the newspaper discourse which is considered as an important genre in the field. As such, this study set out to compare the frequency of different types of textual and interpersonal metadiscourse markers in English and Persian Economic news articles. The logic behind considering this genre was that Economic news reports are undoubtedly among the most widely read newspaper articles by Iranian people nowadays because of the current economic situation in Iran.

\section{Methodology}

\subsection{Materials}

This study was an attempt to comparatively investigate the type and frequency of metadiscourse markers employed in Economic articles in English and Persian newspapers. Accordingly, the corpus data were collected from the online archive (2013-2014) of the leading newspapers published periodically in Iran and United State. Using random sampling, from among 50 articles, a total of 10 news articles, 5 in each language, were selected. The logic behind using random sampling relied on the fact that it would help the researchers bring the problem of particularity of writers' styles under control. To have an equal amount of data in both languages, the first 1000 words from each text were analyzed. The texts were also selected from the same field; i.e. Economy. This would ensure comparability of the texts because, as some practitioners of the field (e.g., Thompson, 2001; Dafouz-Milne, 2003) maintain, the type and frequency of the linguistic elements such as metadiscourse markers in a given text may be considerably influenced by the topic of the text. The most reliable national news agencies like IRNA, IPNA, and ISNA were considered as the sources for selecting the Persian news articles. The English articles were also selected from the leading American newspapers such as The New York Times, Washington Times, and USA Today.

\subsection{Data Collection Procedures}

To reach the purpose of the study, 10 news articles (5 from each language) were randomly selected from among 50 articles in the Economic sections of the newspapers. The analysis of the type and frequency of the metadiscourse markers used in the selected texts was based on the Kopple's (1985) taxonomy, which would follow.

\subsection{Vande Koppel's Metadiscourse Markers' Taxonomy}

Kopple (1985) introduced the first sophisticated classification of the metadiscourse markers based on their functions in the text. In his classification system, Kopple divided two main categories of textual and interpersonal items into seven different classes, which would follow. The first four categories are considered as textual metadiscourse markers and the last three categories as interpersonal metadiscourse markers.

1. Text Connectives: these are linguistic items employed by writers in order to link different parts of a text or different ideas presented in the text. they include phrases or words that show the sequence of the ideas (e.g., 
first, then, after that), expressions that indicate logical or temporal relationships (e.g., as a consequence, at the same time, however), reminders of the previous ideas or materials (e.g., as mentioned before, as we saw earlier), expressions that point to the upcoming materials (e.g., details will be discussed in the forthcoming chapter), and words or phrases that point to the main topic of a sentence or text as a whole (e.g., with regard to, considering, regarding).

2. Code Glosses: these items are used by writers to ensure the readers understand the meanings of specific elements, phrases, or idioms (e.g. that is, it means that, in other words). Code glosses are further divided into three main subcategories of Defining (e.g., it is defined as), Explaining (e.g., it means that, namely), and Delimiting (e.g., somewhat, to a certain degree)

3. Illocution Markers: They can be defined as linguistic elements used in a given text so as to signal the readers what specific speech or discourse act the writer is performing in a given point in the text (e.g., to sum up, I hypothesize that, the purpose is that,).

4. Narrators: They are expressions that inform readers who has said or written a given idea or comment (e.g. as $X$ states, according to $X, X$ and $Y$ claimed that).

5. Validity/modality markers: as a category of interpersonal markers, validity markers are elements that are employed by writers in order to express their certainty or uncertainty about a given idea or comment presented in the text. By applying such linguistic elements in their texts, authors would be able to indicate the extent to which the text's content is valid. Kopple classified them into three subcategories; namely, Hedges (e.g., perhaps, probably, it is possible that), Emphatics (e.g., indubitably, it is obvious that, clearly), and attributors that are used to refer explicitly to the source of information presented in a text in order to persuade readers (e.g. according to Prime Minister, as $X$ remarked).

6. Attitude Markers: They help the readers to grasp the author's attitude toward a specific idea or a given material in the text (e.g. it is interesting, surprisingly, considerably).

7. Commentary: They are applied by authors so as to establish a relationship with the readers/audience (e.g. you may not agree that, dear reader).

To analyze the type and frequency of the metadiscourse markers utilized by Persian authors in their texts, the researchers made an attempt to take into consideration the proper Persian equivalents for each subcategory introduced in Kopple's taxonomy. Some instances of such equivalents and their corresponding English items for textual metadiscourse markers are represented in Table 1.

Table 1. Sample Persian equivalents for textual metadiscourse markers

\begin{tabular}{|c|c|c|c|}
\hline & Textual markers & Persian Equivalents & English Items \\
\hline \multirow[t]{6}{*}{1} & Text Connectives & & \\
\hline & Sequencers & Б. $\bar{b}$ 吼! a & First, second, then \\
\hline & Logical/Temporal connectors & 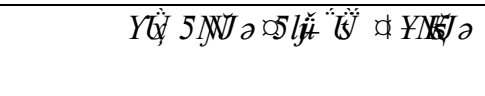 & $\begin{array}{l}\text { As a consequence, accordingly, at } \\
\text { the same time }\end{array}$ \\
\hline & Reminders & 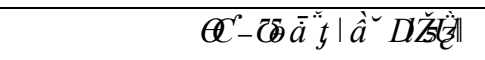 & As mentioned before \\
\hline & Announcements & 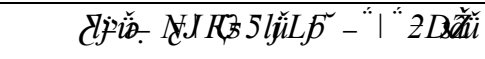 & We will now investigate the issue \\
\hline & Topicalizers & 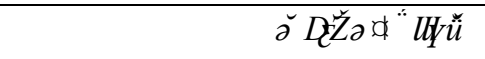 & With regard to, as for \\
\hline \multirow[t]{4}{*}{2} & Code Glosses & & \\
\hline & Defining & 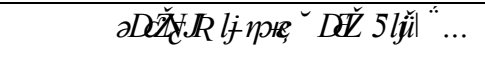 & It can be defined as... \\
\hline & Explaining & 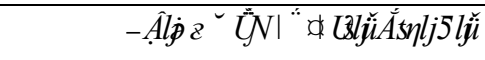 & In other words, it means that \\
\hline & Delimiting & 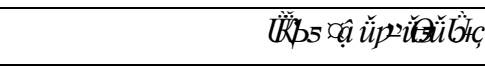 & Relatively, somewhat \\
\hline 3 & Illocution markers & 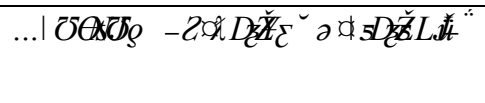 & $\begin{array}{l}\text { As an example, to sum up, suppose } \\
\text { that... }\end{array}$ \\
\hline 4 & Narrators & 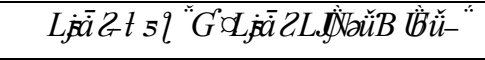 & As $X$ claims, according to $X$ \\
\hline
\end{tabular}

The sample Persian Equivalents for interpersonal metadiscourse markers are also demonstrated in Table 2.

Table 2. Sample Persian equivalents for interpersonal metadiscourse markers

\begin{tabular}{|c|c|c|c|}
\hline & Textual markers & Persian Equivalents & English Items \\
\hline 1 & Validity markers & & \\
\hline & Hedges & 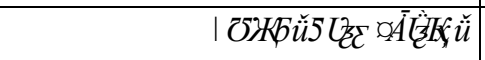 & Probably, it is possible that \\
\hline & Emphatics & 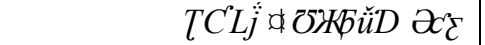 & It is clear that, indubitably \\
\hline
\end{tabular}




\begin{tabular}{|c|c|c|c|}
\hline & Attributors & 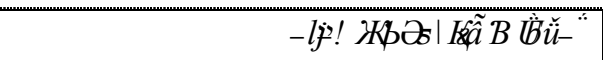 & According to prime minister \\
\hline 2 & Attitude markers & 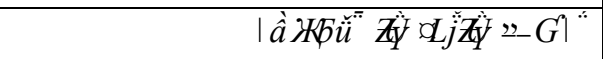 & Surprisingly, it is interesting \\
\hline 3 & Commentary & & \\
\hline & $\begin{array}{l}\text { Comment on readers' moods } \\
\text { and views }\end{array}$ & 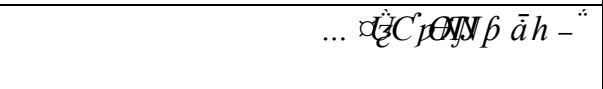 & Contrary to your opinion, ... \\
\hline & $\begin{array}{l}\text { Comment on reading } \\
\text { procedures }\end{array}$ & 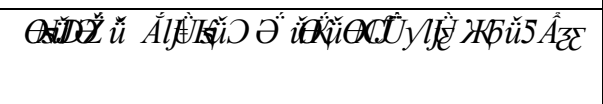 & $\begin{array}{l}\text { You may wish to read the last chapter } \\
\text { first }\end{array}$ \\
\hline & $\begin{array}{l}\text { Comment on anticipations } \\
\text { for readers }\end{array}$ & 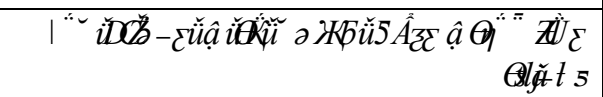 & \\
\hline & $\begin{array}{l}\text { Comment on author-reader } \\
\text { relationships }\end{array}$ & 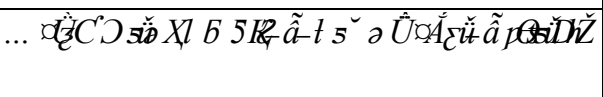 & $\begin{array}{l}\text { Dear reader, considering your } \\
\text { knowledge, ... }\end{array}$ \\
\hline
\end{tabular}

For the purpose of specifying the type and frequency of occurrence of metadiscourse markers in each text, the researchers employed the opinions of two specialists in the field. Their opinions were of great help in not only identifying the metadiscourse markers but also consistently coding the related texts. The inter-rater reliability of the coders was estimated, which turned out to be 0.80 . Having identified and categorized the metadiscourse markers, the researchers conducted a quantitative analysis in order to determine the frequency of different types of textual and interpersonal metadiscourse markers employed in each set of texts. It should be noted here that although a given metadiscourse marker may functionally play different roles in different contexts, the primary function of each marker in the related context was determined as the basis for the analysis of the metadiscourse markers used in these texts.

Finally the collected data were analyzed using non-parametrical means, viz, Mann-Whitney U test, to see whether or not the differences between the two sets of data in terms of frequency of metadiscourse items were significant. The reason for selecting Mann-Whitney $U$ test was that the metadiscourse elements employed in the sample news articles did not enjoy a normal distribution.

To conclude, in this study, the metadiscourse element used in both English and their corresponding Persian texts were first qualitatively analyzed based on their function in the related context so as to specify and classify them into different categories. In the next stage, the collected data were quantitatively analyzed in order to determine their frequency of occurrence in a given text and to realize whether there was a statistically significant difference between two sets of corpus data in this respect.

\section{Results and Discussion}

As mentioned, the collected data were analyzed via non-parametrical means (Mann-Whitney U test). Regarding textual metadiscourse markers, as it can be induced from Table 3, the findings demonstrate that there is a statistically significant difference in the Announcements frequency $(\mathrm{p}=.034)$ between American and Persian economic news reports. Moreover, both sets of texts enjoyed a high frequency of occurrence of Logical Connectors, with the Persian writers using more such elements in their texts than American writers (70 vs. 50 items, respectively). Within the categories of textual markers, illocution markers were used the least in both sets of data. For further analysis of each category and sub-category of textual metadiscourse markers, see Table 3 .

Table 3. Results for textual metadiscourse markers' subcategories

\begin{tabular}{llccc}
\hline $\begin{array}{c}\text { Macro } \\
\text { Category }\end{array}$ & $\begin{array}{c}\text { Sub } \\
\text { Category }\end{array}$ & $\begin{array}{c}\text { No. of Markers } \\
\text { Persians }\end{array}$ & $\begin{array}{c}\text { No. of Markers } \\
\text { Americans }\end{array}$ & $\begin{array}{c}\text { Mann-Whitney } \\
\text { U Test Asymp. } \\
\text { Sig (2-tailed) }\end{array}$ \\
\hline 1.Text & Sequencers & 33 & 20 & 0.525 \\
Connectives & Logical connectors & 70 & 50 & 0.834 \\
& Reminders & 18 & 11 & 0.454 \\
& Announcements & 18 & 09 & 0.034 \\
& Topicalizers & 27 & 20 & 0.592 \\
\hline 2.Code & Defining & 02 & 04 & 0.419 \\
Glosses & Explaining & 10 & 12 & 0.729 \\
& Delimiting & 11 & 09 & 0.661 \\
\hline 3.Illocution & $\ldots \ldots \ldots \ldots \ldots . .$. & 02 & 03 & 0.549 \\
Markers & & & & \\
\hline 4.Narrators & $\ldots \ldots \ldots \ldots \ldots \ldots . .$. & 20 & & \\
& & & & \\
\hline
\end{tabular}

With respect to interpersonal metadiscourse markers' categories and sub categories, the results of statistical analysis, as shown in Table 4, reveal that most of the markers are used to the same extent in both sets of data, with the exception of Attributors. Although American authors indicated more tendency towards using attributors in reporting the Economic 
news, but the difference is not too much to be statistically significant. The only statistically significant difference in terms of frequency of interpersonal metadiscourse markers is found in Emphatics $(p=.041)$. Accordingly, when it comes to employing emphatic items (e.g., clearly, undoubtedly) in their texts, American and Persian writers act differently. Figures in the Table 4 show that Persian authors are more in favour of using such linguistic elements in their texts than are their corresponding American writers. Finally, Commentaries were the least frequent category of interpersonal markers both groups of writers tended to employ in writing Economic news reports.

Table 4. Results for interpersonal metadiscourse markers' subcategories

\begin{tabular}{|c|c|c|c|c|}
\hline $\begin{array}{c}\text { Macro } \\
\text { Category }\end{array}$ & $\begin{array}{c}\text { Sub } \\
\text { Category }\end{array}$ & $\begin{array}{l}\text { No. of Markers } \\
\text { Persians }\end{array}$ & $\begin{array}{c}\text { No. of Markers } \\
\text { Americans }\end{array}$ & $\begin{array}{l}\text { Mann-Whitney } \\
\text { U Test Asymp. } \\
\text { Sig (2-tailed) }\end{array}$ \\
\hline 1.Validity & Hedges & 15 & 20 & 0.395 \\
\hline \multirow[t]{2}{*}{ Markers } & Emphatics & 14 & 04 & 0.041 \\
\hline & Attributors & 57 & 71 & 0.462 \\
\hline $\begin{array}{l}\text { 2.Attitude } \\
\text { Markers }\end{array}$ & …................ & 13 & 16 & 0.911 \\
\hline \multirow[t]{4}{*}{ 3.Commentry } & $\begin{array}{l}\text { Comment on readers' } \\
\text { moods and views }\end{array}$ & 05 & 03 & 0.729 \\
\hline & $\begin{array}{l}\text { Comment on reading } \\
\text { procedures }\end{array}$ & 01 & 00 & 0.317 \\
\hline & $\begin{array}{l}\text { Comment on antici- } \\
\text { pations for readers }\end{array}$ & 03 & 05 & 0.339 \\
\hline & $\begin{array}{l}\text { Comment on author- } \\
\text { reader relationship }\end{array}$ & 06 & 10 & 0.334 \\
\hline
\end{tabular}

Table 5 below illustrates the overall percentages of the textual and interpersonal metadiscourse markers' macrocategories used in Economic texts written by both American and Persian authors. In the vein of textual macrocategories, in the texts written by Iranian writers, text connectives are the most numerous markers $(50.30 \%)$, followed by narrators $(7.57 \%)$, code glosses $(6.96 \%)$, and finally illocution markers $(.6 \%)$. In the American group's texts, text connectives are also more frequently used (38.32\%) than other markers, followed by code glosses $(8.71 \%)$, narrators (6.96\%), and finally illocution markers (1.4\%). Following the interpersonal metadiscourse markers' macro-categories, in texts written by Iranian writers, validity markers capture the most proportion (26.06\%), followed by commentary (4.54\%), and at last attitude markers (3.93\%). Similarly, in the texts written by corresponding American authors, validity markers are the most numerous interpersonal marker employed (33.10\%), followed by commentary $(6.27 \%)$, and finally attitude markers that are situated in the last place $(5.57 \%)$.

Table 5. Results for textual and interpersonal metadiscourse markers' macro-categories

\begin{tabular}{lcccc}
\hline $\begin{array}{l}\text { Macro } \\
\text { Category }\end{array}$ & $\begin{array}{c}\text { No. of Markers } \\
\text { Persians }\end{array}$ & $\begin{array}{c}\text { No. of Markers } \\
\text { Americans }\end{array}$ & $\begin{array}{c}\text { Persian News } \\
\%\end{array}$ & $\begin{array}{c}\text { American News } \\
\%\end{array}$ \\
\hline 1.text connectives & 166 & 110 & 50.30 & 38.32 \\
2.Code Glosses & 23 & 25 & 6.96 & 8.71 \\
3.Illocution Markers & 02 & 03 & 0.6 & 1.4 \\
4.Narrators & 25 & 20 & 7.57 & 6.96 \\
5. Validity Markers & 86 & 95 & 26.06 & 33.10 \\
6.Attitude Markers & 13 & 16 & 3.93 & 5.57 \\
7.Commentry & 15 & 18 & 4.54 & 6.27 \\
\hline
\end{tabular}

To conclude, the results of the statistical analysis represented in Tables 3, 4, and 5 clearly reveal that there exist many similarities between two sets of data concerning the frequency of different metadiscourse markers. Regarding the textual markers in the macro-category of Text Connectives, the logical connectors appear to be the most frequent items utilized in the Economic texts written by both American and Persian authors. Alternatively, neither American nor Persian writers seem to favour using illocution markers in their texts. The only statistically significant difference between the two groups is found in the frequency of the announcements $(p=.034)$ which are a subcategory of text connectives. In fact, the frequency of announcements employed by Persian authors was twice more than that of American writers. 
It is clearly observed that American authors utilized all subcategories of interpersonal markers slightly more frequently in their texts except for emphatics. In this case, as Table 4 illustrates, the difference between two groups is statistically significant ( $\mathrm{p}=.041$ ). In fact, Persian writers made use of emphatics in their texts far more frequently than the American group. Contrary to Persian group, American writers appear to use hedges more frequently in their texts in order to show uncertainty about a given idea.

As Hyland (2005) maintains, metadiscourse markers are universal features of texture by which authors would be able to explicitly organize and evaluate their texts to communicate with the readers. This claim is evidently substantiated by the results in this study as both groups of writers made a logical use of these linguistic elements. Furthermore, the findings also indicate that both American and Persian authors used textual metadiscourse markers far more frequently in their texts than interpersonal markers. This finding is also in line with the claim made by Hempel and Degand (2008) on the importance of textual markers used in various texts. In this regard, Hempel and Degand believe that textual metadiscourse resources are the authors' conscious stratagem in constructing the propositional content which they aim to convey to the addressee. In the vein of textual metadiscourse markers, the results of the analyses reveal that text connectives are the most frequent items used by Persian writers compared to the American group. This is acknowledged by the results found in the study conducted by Simin and Tavangar (2009). Based on their findings, they concluded that all Iranian EFL writers with different proficiency levels used text connectives as the most frequently used textual markers in their English texts.

By contrast, the findings of the present study suggest that interpersonal markers are used more frequently in the Economic texts written by American writers than those written by Persian authors (see Table 5). This is quite consistent with the results of the studies conducted by Abdollahzadeh (2003) and Yazdani, Sharifi, and Elyassi (2014). In both projects, researchers made a comparative investigation of interpersonal metadiscourse markers employed by both American and Iranian authors in their texts. The results indicated that American writers tended to use these items in writing academic texts more than that of Iranian authors. One possible reason for this tendency, according to Leki (2002), would be that the writers' cultural background has a great bearing on their writing styles. In fact, American authors are so concerned about the reader-writer interaction that they prefer to use more interpersonal markers in their texts in order to establish a strong solidarity with their target audience. This idea is supported by the results of this study in that American writers appeared to use hedges more frequently in their texts compared to Persian writers. As Hyland (2005) claims, hedges play a pivotal role in creating rapport between authors and their respective audiences. Contrary to American group, Persian writers appear to use more emphatics (e.g., certainly, undoubtedly) in their texts in order to show they are certain about a given idea. Such a difference is clearly indicative of the fact that cultural differences are certainly at work in text creation. This reality is appreciated in the study carried out by Noorian and Biria (2010) in which they concluded that while Persian writers favoured the use of emphatics in their texts, the American group showed a great tendency towards using hedges. Based on their findings, they claimed that Persian writers tend to be more assertive in their writings, whereas the American authors tried to be more polite to their readers by limiting the use of emphatics in their texts.

\section{Conclusion}

This study set out to explore the similarities and differences between English and Persian Economic news reports in terms of the frequency of textual and interpersonal metadiscourse markers used. Using 10 news articles, 5 from each language, the researchers analyzed the data based on the Kopple's (1985) taxonomy of metadiscourse markers. Regarding the textual metadiscourse markers, the results of the analyses revealed that both groups of writers utilized textual markers, especially text connectives, far more frequently in their texts compared to interpersonal markers. Surprisingly, the only statistically significant difference between two sets of data was found in the frequency of Announcements ( $\mathrm{p}=.034)$.

The results of interpersonal markers, on the other hand, indicated that the American group used these items slightly more than Persian writers. However, there was a difference between two groups in the case of certainty markers. In fact, as it has been acknowledged in similar studies (Abdollahzadeh, 2007; Noorian \& Biria, 2010), while the Persian authors appeared to use more emphatics in their texts, the American group tended to make use of hedges more in writing the Economic news reports. Accordingly, it can be concluded that contrary to Persian writers, American Authors may be less assertive, more conservative, and more inclined to express their affective values in their writings. In the case of American writers, the dominance of the use of interpersonal markers can be attributed to the cultural background of the writers in that they show more tendencies towards establishing reader-writer rapport in their texts.

Due to the fact that metadiscourse is a branch of pragmatics, teachers and practitioners of the field should pay more attention to this aspect of language because, as Crismore, Markkanen, and Steffensen (1993) maintain, gaining knowledge in this area is rather difficult. As such, metadiscourse studies such as this may be of great help to both foreign language teachers and learners by revealing the possible problematic areas in the utility of metadiscourse markers in the texts. Students need to become familiar with the concepts of cohesion and coherence in the text and the only way to reach this end is through learning the functional roles of textual and interpersonal metadiscourse markers in different contexts and genres. 


\section{References}

Abdi, R. (2002). Interpersonal metadiscourse: An indicator of interaction and identity. Discourse Studies, 4(2), $139-145$.

Abdollahzadeh, E. (2003). Interpersonal metadiscourse in ELT papers by Iranian and Anglo-American academic writers. Paper presented at the International Conference on Multiculturalism in ELT Practice, Baskent University, Turkey

Abdollahzadeh, E. (2007). Writer's presence in Persian and English newspaper editorial. Paper presented at the International Conference on Systemic Functional Linguistics, Odense, Denmark.

Crismore, A., \& Abdollahzadeh, E. (2010). A review of recent metadiscourse studies: The Iranian context. NJES, 9(2), 195-219.

Crismore, A., Markkanen, R., \& Steffensen, M.S. (1993). Metadiscourse in persuasive writing: A study of text written by American and Finnish university students. Written Communication, 10(1), 39-71. doi: $10.1177 / 0741088393010001002$.

Dafouz-Milne, E. (2003). Metadiscourse revisited: A contrastive study of persuasive writing in professional discourse. Estudios Ingleses de la Universidad Complutense, 11, 29-57.

Dafouz-Milne, E. (2008). The pragmatic role of textual and interpersonal metadiscourse markers in the construction and attainment of persuasion: A cross-linguistic study of newspaper discourse. Journal of Pragmatics, 40, 95-113.

Halliday, M. A. K. (1994). An Introduction to Functional Grammar (2 ${ }^{\text {nd }}$ Ed.). London: Edward Arnold.

Hashemi, M.R., \& Golparvar, E. (2012). Exploring metadiscourse markers in Persian news reports. International Journal of Social Science Tomorrow, 1(2), 1-6.

Hempel, S., \& Degand, L. (2008). Sequencers in different text genres: Academic writing, journalese and fiction. Journal of Pragmatics, 40, 676-693.

Thompson, G. (2001). Interaction in academic writing: Learning to argue with the reader. Applied Linguistics, 22(1), 58-78.

Hyland, K. (1998). Exploring corporate rhetoric: Metadiscourse in the CEO's letter. Journal of Business Communication, 35(2), 224-245.

Hyland, K. (2005). Metadiscourse: Exploring Interaction in Writing. London: Continuum.

Hyland, K., \& Tse, P. (2004). Metadiscourse in academic writing: A reappraisal. Applied Linguistics, 25 (2), $156-177$.

Leki, I. (2002). Second language writing. In R. B. Kaplan (Ed), The Oxford Handbook of Applied Linguistics (pp. 6069). New York: Oxford University Press.

Noorian, M., \& Biria, R. (2010). Interpersonal metadiscourse in persuasive journalism: A study texts by American and Iranian EFL columnists. Journal of Modern Languages, 20, 64-79.

Simin, S., \& Tavangar, M. (2009). Metadiscourse knowledge and use in Iranian EFL writing. Asian EFL Journal, 11(1), 230-255.

VahidDastjerdi, H., \& Shirzad, M. (2010). The impact of explicit instruction of metadiscourse markers on EFL learners' writing performance. Journal of Teaching Language Skills, 2(2), 155-174.

Vande Kopple, W. J. (1985). Discourse about discourse. College Composition and Communication, 36, 82-93.

Yazdani, S., Sharifi, SH., \& Elyassi, M. (2014). Interactional metadiscourse in English and Persian news articles about 9/11. Theory and Practice in Language Studies, 4 (2), 428-434. doi:10.4304/tpls.4.2.428-434b

Zarei, G. R., \& Mansoori, S. (2011). A contrastive study on metadiscourse elements used in humanities vs. nonhumanities across Persian and English. English Language Teaching, 4(1), 42-50. 